\title{
Anthelmintic Activity of Petiveria alliacea, Bursera simaruba y Casearia corymbosa Collected in Two Seasons on Ancylostoma caninum, Haemonchus placei and Cyathostomins
}

\section{Gabriela Janett Flota-Burgos ${ }^{1}$, José Alberto Rosado-Aguilar ${ }^{1 *}$, Roger Iván Rodríguez-Vivas ${ }^{1}$, Rocío Borges-Argáez ${ }^{2}$, Marcela Gamboa-Angulo $^{2}$ and Cintli Martínez-Ortiz-de-Montellano ${ }^{3}$}

${ }^{1}$ Departamento de Salud Animal, Facultad de Medicina Veterinaria y Zootecnia, Universidad Autónoma de Yucatán, México

${ }^{2}$ Unidad de Biotecnología, Centro de Investigación Científica de Yucatán A.C., México

${ }^{3}$ Departamento de Parasitología, Facultad de Medicina Veterinaria y Zootecnia, Universidad Nacional Autónoma de México, México

*Corresponding Author: José Alberto Rosado-Aguilar, Departamento de Salud Animal, Facultad de Medicina Veterinaria y Zootecnia, Universidad Autónoma de Yucatán, México.
Received: November 03, 2020

Published: November 18, 2020

(C) All rights are reserved by José Alberto

Rosado-Aguilar., et al.

\section{Abstract}

The aim of the study was to evaluate methanolic extracts from the stem and leaves of Petiveria alliacea, bark of Bursera simaruba and Casearia corymbosa collected in two seasons on eggs of Ancylostoma caninum, Haemonchus placei and cyathostomin. The egg hatch inhibition assay was used at concentrations of 3600, 2400,1200, 600 and $300 \mu \mathrm{g} / \mathrm{ml}$. The extracts with high activity were also evaluated at 300, 150, 75 and $37.5 \mu \mathrm{g} / \mathrm{ml}$. Lethal concentrations were determined at $50 \%\left(\mathrm{LC}_{50}\right)$ and $99 \%$ ( $\mathrm{LC}_{99}$ ), as well as the confidence intervals at $95 \%$. Differences $(\mathrm{p}<0.05)$ between control and evaluated concentrations were analyzed. The $P$. alliacea extract collected in the rainy season (CRS) showed a percentage of egg hatch inhibition (PEHI) $\geq 91.6 \%$ from $150 \mu \mathrm{g} / \mathrm{ml}$, and ovicidal effect ( $\geq 90.1 \%$ ) from $150 \mu \mathrm{g} / \mathrm{ml}$ with stem and $300 \mu \mathrm{g} / \mathrm{ml}$ with leaves in both parameters on the three genera of gastrointestinal nematodes evaluated. The B. simaruba extract CRS $(3600 \mu \mathrm{g} / \mathrm{ml})$ showed a PEHI of 95.4, 25.4 and 56.3\% against A. caninum, H. placei and cyathostomins, respectively. While the $C$. corymbosa extract at the same season and concentration had the highest PEHI of 55.1, 74.0 and $56.4 \%$ against the three nematodes, respectively. The effect of $B$. simaruba and $C$. corymbosa on the eggs was the failure of the $\mathrm{L}_{1}$ larvae to hatch (23.7 - 95.1\% and $30.4-60.8 \%$, respectively, at $3600 \mu \mathrm{g} / \mathrm{ml}$ ). Additionally, it was observed that $C$. corymbosa extract caused morphological damage to the larvae that hatched (100\% from $1200 \mu \mathrm{g} / \mathrm{ml})$. Extracts from the stem of $P$. alliacea CRS showed the lowest $\operatorname{LC}_{50}(33.3,78.9$ y $68.6 \mu \mathrm{g} / \mathrm{ml})$ and $\mathrm{LC}_{99}(79.5,178.0$ and $277.4 \mu \mathrm{g} / \mathrm{ml})$ against $A$. caninum, H. placei and cyathostomins, respectively. It is concluded that the methanolic extracts of $P$. alliacea, $B$. simaruba and $C$. corymbosa collected in rainy season showed the highest anthelmintic activity on eggs of A. caninum, $H$. placei and cyathostomins. The stem of $P$. alliacea CRS has high ovicidal activity on the three nematodes, representing a potential alternative control with a broad spectrum against the main nematodes of domestic animals.

Keywords: Control Alternatives; Gastrointestinal Nematodes; Methanolic Extracts; Petiveria alliacea; Bursera simaruba; Casearia corymbosa

\section{Abbreviations}

CRS: Collected in the Rainy Season; CDS: Collected in the Dry Season; $\mathrm{LC}_{50}$ : Lethal Concentration at $50 \%$; $\mathrm{LC}_{99}$ : Lethal Concentration at 99\%; GIN: Gastrointestinal Nematodes; WAAVP: World Association for the Advancement of Veterinary Parasitology; PBS: Phosphate Buffer Solution; PEHI: Percentage of Egg Hatch Inhibition; OA: Ovicidal Activity; LFE $\mathrm{L}_{1}$ : Larvae Failing Eclosion 


\section{Introduction}

In tropical and subtropical regions, gastrointestinal nematodes (GIN) are the main parasites that cause health problems in domestic animals as well as economic losses to production and because of their zoonotic potential, they have a negative impact on public health. Among the GIN with the highest prevalence and high pathogenicity worldwide are Ancylostoma caninum in dogs, Haemonchus placei in cattle and cyathostomins in horses [1-3].

Due to the importance of GINs and their negative impact, programs have been designed to prevent and control them, and a large amount of money has been invested in the purchase of anthelmintics. However, traditional prevention and control programs have been based on frequent and irrational administration of these chemicals, which has favored the selection of GIN populations that are resistant to most of them $[4,5]$. Worldwide, there have been reports of anthelmintic resistance of Ancylostoma spp. to benzimidazoles, pyrantel and ivermectin [6,7]. In the case of Haemonchus spp. reports indicate resistance to salicylanilides, benzimidazoles, imidazothiazole and ivermectin [8-10], while the current situation of resistance by cyathostomins includes benzimidazoles, pyrimidines and macrocyclic lactones [11-13].

Due to the lack of effectiveness of commercial anthelmintics and residues in animal products for human consumption, new control alternatives have been employed. Certain plant extracts have been shown to possess anthelmintic activity by reducing fecal egg count and affecting viability. This has motivated the exploration and search for plants containing secondary metabolites with anthelmintic properties against GIN [14]. In southeastern Mexico, preliminary studies have been conducted to evaluate the anthelmintic potential of Petiveria alliacea, Bursera simaruba and Casearia corymbosa for nematode control. Arjona-Cambranes., et al. [15] (abstract of a congress) observed that $P$. alliacea extract had a percentage of egg hatch inhibition (PEHI) above $90 \%$ in A. caninum eggs (concentration of $600 \mu \mathrm{g} / \mathrm{ml}$ ), while the $B$. simaruba and C. corymbosa extracts reported a PEHI of $9.1 \%$ and $34.5 \%$ (concentration of $3600 \mu \mathrm{g} / \mathrm{ml}$ ), respectively. On the other hand, Flota-Burgos., et al. [17] evaluated the efficacy of an extract of $P$. alliacea $(300 \mu \mathrm{g} / \mathrm{ml})$ on cyathostomin eggs, finding a PEHI $>90 \%$.

Most studies of extracts against GIN challenge a single genus of nematode, leaving it unclear whether such extracts possess broad anthelmintic spectrum against two or more GIN genera.

\section{Aim of the Study}

The aim of the present study was to evaluate the anthelmintic activity of the methanolic extract of $P$. alliacea, $B$. simaruba and $C$. corymbosa on eggs of $A$. caninum, H. placei and cyathostomins affecting canines, cattle and horses, respectively.

\section{Materials and Methods}

Place of study

This study was carried out at the Laboratory of Parasitology (Diagnostic Unit) of the Faculty of Veterinary Medicine and Zootechny, Universidad Autónoma de Yucatán, located in Yucatan, Mexico $\left(19^{\circ} 30^{\prime}, 21^{\circ} 35^{\prime} \mathrm{N} ; 87^{\circ} 30^{\prime}, 90^{\circ} 24^{\prime} \mathrm{W}\right)$. The state of Yucatan is characterized by a predominantly warm sub-humid climate (Aw), with an average annual temperature of $26^{\circ} \mathrm{C}$ and an annual rainfall of 1,000 mm. There are mainly two seasons: dry (November-May) and rainy (June-October) [18].

\section{Methanolic plant extracts}

The evaluation was carried out on extracts of stem and leaves of $P$. alliacea, bark of B. simaruba and bark of $C$. corymbosa, which were collected during the dry season (March-April) and the rainy season (August-September). Once the plant material was collected, it was separated according to the plant and structures mentioned above and placed in a drying oven at $40^{\circ} \mathrm{C}$ for two days. The dry material was then ground with the aid of an electric mill to reduce particle size to $5 \mathrm{~mm}$. Two extractions were performed, with a duration of $24 \mathrm{~h}$ each, using methanol $(\mathrm{MeOH})$ as solvent at a rate of $30 \mathrm{ml}$ per $25 \mathrm{~g}$ of ground material. At the end of each extraction period, the solvent of the ground material was decanted through a filter paper and deposited in glass flasks. The concentration of the extract was achieved by removing the solvent at reduced pressure in a rotary evaporator (Rotavapor Büichi ${ }^{\circledR}$ ). The methanolic extracts were stored in glass vials $\left(4^{\circ} \mathrm{C}\right)$ until they were used [19].

\section{Collection of nematode eggs}

Feces were collected from canines, cattle and horses naturally infected with $A$. caninum, $H$. placei and cyathostomins, respectively. Stool cultures were performed to identify morphologically the genera of $\mathrm{L}_{3}$ larvae from each animal donor. Prior to sample processing, each sample was centrifugally floated to ensure that the eggs were in the morula phase and that larval formation had not yet begun [20]. The feces were macerated with purified water and the mixture was filtered through non-sterile gauze. The liquid obtained was placed in $45 \mathrm{ml}$ plastic tubes and centrifuged at $1500 \mathrm{rpm}$ for 
5 minutes. Afterwards, the supernatant was discarded, and a sugar saturated solution was added (density: 1.280). With the help of a vortex, the mixture was homogenized and centrifuged again. The eggs from the surface portion were collected with an inoculation loop and suspended in a phosphate buffer solution (PBS). Three washings with PBS were performed to remove any traces of the saturated sugar solution that might have been present in the suspension. The concentration of the recovered eggs per milliliter was determined and the suspension was diluted to a solution of 400 eggs/ml $[17,21]$.

\section{Egg hatch inhibition assay}

The egg hatch inhibition assay was performed following the guidelines of the World Association for the Advancement of Veterinary Parasitology (WAAVP) [4]. Concentrations of 3600, 2400, 1200,600 and $300 \mu \mathrm{g} / \mathrm{ml}$ were evaluated, and extracts showing $\geq 90 \%$ of anthelmintic activity at concentrations of 600 and 300 $\mu \mathrm{g} / \mathrm{ml}$ were evaluated at lower concentrations $(150,75$ and 37.5 $\mu \mathrm{g} / \mathrm{ml})$. Three repetitions were made for each concentration. A mixture of $95 \%$ PBS $+5 \%$ absolute ethanol was used as solvent. This mixture was used as a negative control and did not affect the hatching of the eggs ( $\geq 90 \%)$. Thiabendazole $(0.1 \mu \mathrm{g} / \mathrm{ml})$ was used as a positive control. An ultrasonic bath (Branson ${ }^{\circledR}$ ) was used to optimize the dilution of the extracts at the different concentrations mentioned. In the culture plates of 24 wells, $0.5 \mathrm{ml}$ of the egg solution (approximately 200 eggs) and $0.5 \mathrm{ml}$ of the diluted extract were deposited in each well (total volume of each well: $1.0 \mathrm{ml}$ ). The culture plates were incubated at $28^{\circ} \mathrm{C}$ for $48 \mathrm{~h}$. After the incubation time, two drops of lugol were added to stop the hatching process. Only those plates whose negative controls obtained a hatching percentage equal to or greater than $80 \%$ were analyzed. The contents of each well were deposited in McMaster cameras, examined with a microscope $(10 \times)$ to count the morulated eggs (ovicidal activity), eggs containing a larva (larvae failing eclosion) and $\mathrm{L}_{1}$ larvae [17].

Results analysis

\section{Extract activity and effect}

Hatching rate and egg hatch inhibition were calculated with the following formula $[17,22]$ :

- $\quad \%$ hatch: (larvae $\mathrm{L}_{1} /$ morulated eggs + eggs containing larvae + larvae $\mathrm{L}_{1}$ ) x 100 .

- $\%$ egg hatch inhibition: $100-\%$ hatch.

The formulas proposed by Vargas-Magaña., et al. [20] were em- ployed to calculate the percentage of eggs that failed to form larvae (ovicidal activity; \%OA) and the percentage of $\mathrm{L}_{1}$ larvae failing eclosion (\%LFE):

- $\quad \%$ OA: (morulated eggs/morulated eggs+ eggs containing a larva $+\mathrm{L}_{1}$ larvae) $\times 100$

- $\quad \%$ LFE: (eggs containing a larva/morulated eggs + eggs containing a larva $+\mathrm{L}_{1}$ larvae) $\times 100$

\section{Statistical analysis}

An analysis of variance (generalized linear models) was used to identify statistically significant differences between controls, evaluated concentrations and collection seasons (Statgraphics 5.1).

Lethal concentrations at 50\% $\left(\mathrm{LC}_{50}\right), 99 \%\left(\mathrm{LC}_{99}\right)$ and their $95 \%$ confidence intervals were determined using concentration-response analysis (Probit Analysis) [23].

\section{Results and Discussion}

Several studies have reported on the anthelmintic activity of plants against GIN; most of them address this potential by focusing on one genus only. The use of plant extracts as an alternative to control GIN should consider the search for plants with a broad antiparasitic spectrum. In this study, the extracts collected in the rainy season (CRS) of the three plants evaluated showed greater anthelmintic activity against $A$. caninum, $H$. placei and cyathostomins. The extracts of $P$. alliacea demonstrated the highest anthelmintic activity against the three different nematode genera.

\section{Petiveria alliacea extracts}

Since $P$. alliacea extracts showed percentages of inhibition > $90 \%$ at concentrations of 600 and $300 \mu \mathrm{g} / \mathrm{ml}$, they were evaluated at concentrations of 150, 75 and $37.5 \mu \mathrm{g} / \mathrm{ml}$ (Table 1). The highest PEHI of $P$. alliacea were obtained from the CRS extracts. When each of the plant parts were evaluated, it was found that the stem showed higher anthelmintic activity at a lower concentration $(\mathrm{p}<$ 0.05 ) than the leaves, independently of the nematode genus evaluated. The stem extract of $P$. alliacea CRS showed a PEHI $>91 \%$ from the concentration of $150 \mu \mathrm{g} / \mathrm{ml}(98.4 \%, 91.6 \%$ and $94.6 \%$, against eggs of A. caninum, H. placei and cyathostomins, respectively), while the extract belonging to the leaves CRS reached a similar PEHI with double the concentration $(99.2 \%, 94.3 \%$ and $94.0 \%$ at $300 \mu \mathrm{g} / \mathrm{ml}$, respectively). With respect to $A$. caninum, it was observed that the stem and leaf extracts of $P$. alliacea CRS showed a PEHI $>97 \%$ at 75

Citation: José Alberto Rosado-Aguilar., et al. "Anthelmintic Activity of Petiveria alliacea, Bursera simaruba y Casearia corymbosa Collected in Two Seasons on Ancylostoma caninum, Haemonchus placei and Cyathostomins". Acta Scientific Veterinary Sciences 2.12 (2020): 12-24. 
Anthelmintic Activity of Petiveria alliacea, Bursera simaruba y Casearia corymbosa Collected in Two Seasons on Ancylostoma caninum, Haemonchus placei and Cyathostomins

$\mu \mathrm{g} / \mathrm{ml}$ and $150 \mu \mathrm{g} / \mathrm{ml}$, respectively. This represents half of the concentration required to obtain a similar PEHI against $H$. placei and cyathostomin eggs $(150 \mu \mathrm{g} / \mathrm{ml}$ for stem and $300 \mu \mathrm{g} / \mathrm{ml}$ for leaf $)$. Using the analysis of variance, it was determined that the PEHI (from $75 \mu \mathrm{g} / \mathrm{ml}$ against $A$. caninum eggs and $150 \mu \mathrm{g} / \mathrm{ml}$ against $H$. placei and cyathostomin eggs) of the P. alliacea stem extracts CRS showed no statistical difference $(\mathrm{p}>0.05)$ against the PEHI of the positive control (Thiabendazole), whereas with the leaf extract, this statistical similarity was observed using twice the concentration $(150 \mu \mathrm{g} / \mathrm{ml}$ against $A$. caninum. eggs and $300 \mu \mathrm{g} / \mathrm{ml}$ against $H$. placei and cyathostomin eggs).

\begin{tabular}{|c|c|c|c|c|c|c|c|}
\hline \multirow[t]{2}{*}{ Structure } & \multirow[t]{2}{*}{$\begin{array}{c}\text { Concentration } \\
(\mu \mathrm{g} / \mathrm{ml})\end{array}$} & \multicolumn{2}{|c|}{ Ancylostoma caninum } & \multicolumn{2}{|c|}{ Haemonchus placei } & \multicolumn{2}{|c|}{ Cyathostomins } \\
\hline & & Dry & Rainy & Dry & Rainy & Dry & Rainy \\
\hline \multirow[t]{7}{*}{ Leaf } & Negative control & $0.1(0.9)^{\mathrm{a}}$ & $2.2(0.6)^{\mathrm{a}}$ & $3.2(0.9)^{\mathrm{a}}$ & $3.9(2.3)^{\mathrm{a}}$ & $6.8(2.7)^{\mathrm{a}}$ & $6.0(3.6)^{\mathrm{a}}$ \\
\hline & Positive control & $98.1(1.4)^{* b}$ & $98.2(1.5)^{* b}$ & $97.2(3.1)^{* b}$ & $98.1(1.7)^{* b}$ & $98.6(0.9)^{* \mathrm{~b}}$ & $98.3(0.7)^{* b}$ \\
\hline & 600 & $98.9(0.3)^{* b}$ & $99.8(0.2)^{* b}$ & $96.7(2.2)^{* \mathrm{~b}}$ & $94.9(2.1)^{* \mathrm{~b}}$ & $98.6(0.8)^{* b}$ & $100.0(0.0)^{* b}$ \\
\hline & 300 & $91.7(0.6)^{* c}$ & $99.2(0.3)^{* \mathrm{~b}}$ & $93.1(2.1)^{* \mathrm{~b}}$ & $94.3(1.8)^{* b}$ & $86.5(5.2)^{* c}$ & $94.0(2.6)^{* \mathrm{~b}}$ \\
\hline & 150 & $88.7(1.5)^{* d}$ & $98.9(0.5)^{* b}$ & $88.1(4.4)^{* c}$ & $65.5(3.0)^{* c}$ & $84.3(3.0)^{* d}$ & $88.0(0.4)^{* c}$ \\
\hline & 75 & $27.6(1.2)^{* \mathrm{e}}$ & $38.9(0.8)^{* c}$ & $32.3(6.0)^{* d}$ & $17.9(6.3)^{* d}$ & $62.0(7.9)^{* \mathrm{e}}$ & $63.5(3.5)^{* d}$ \\
\hline & 37.5 & $14.4(0.9)^{* \mathrm{f}}$ & $18.2(0.8)^{* d}$ & $5.2(1.4)^{\mathrm{e}}$ & $8.4(0.6)^{\mathrm{e}}$ & $31.7(8.2)^{* f}$ & $44.2(2.2)^{* \mathrm{e}}$ \\
\hline \multirow[t]{7}{*}{ Stem } & Negative control & $4.1(0.7)^{\mathrm{a}}$ & $2.2(2.3)^{\mathrm{a}}$ & $0.8(0.6)^{\mathrm{a}}$ & $2.2(0.8)^{\mathrm{a}}$ & $5.8(4.8)^{\mathrm{a}}$ & $4.3(3.1)^{\mathrm{a}}$ \\
\hline & Positive Control & $98.2(1.5)^{* b}$ & $98.6(1.2)^{* b}$ & $99.4(0.5)^{* b}$ & $97.8(1.0)^{* \mathrm{~b}}$ & $98.9(1.1)^{* b}$ & $98.5(0.4)^{* b}$ \\
\hline & 600 & $99.6(0.3)^{* b}$ & $99.3(0.5)^{* b}$ & $97.8(0.7)^{* \mathrm{~b}}$ & $94.5(0.3)^{* b}$ & $98.7(1.4)^{* b}$ & $97.7(0.2)^{* b}$ \\
\hline & 300 & $99.6(0.2)^{* \mathrm{~b}}$ & $99.0(0.7)^{* b}$ & $97.0(1.0)^{* b}$ & $91.9(6.1)^{* b}$ & $98.2(0.7)^{* \mathrm{~b}}$ & $97.6(2.1)^{* b}$ \\
\hline & 150 & $97.8(0.9)^{* b}$ & $98.4(0.7)^{* b}$ & $77.2(3.0)^{* c}$ & $91.6(4.7)^{* b}$ & $70.7(3.1)^{* c}$ & $94.6(0.9)^{* b}$ \\
\hline & 75 & $17.5(0.5)^{* c}$ & $97.1(2.3)^{* b}$ & $34.0(1.1)^{* d}$ & $70.6(3.0)^{* c}$ & $27.9(0.5)^{* d}$ & $56.8(1.9)^{* c}$ \\
\hline & 37.5 & $4.5(1.1)^{\mathrm{d}}$ & $40.4(5.5)^{* c}$ & $2.1(0.6)^{\mathrm{e}}$ & $17.6(3.7)^{* \mathrm{~d}}$ & $20.0(8.2)^{* \mathrm{e}}$ & $36.4(5.1)^{* d}$ \\
\hline
\end{tabular}

Table 1: Mean and standard deviation ( \pm ) of the percentage of egg hatch inhibition obtained with Petiveria alliacea extracts on eggs of Ancylostoma caninum, Haemonchus placei and cyathostomins.

* Significant difference with the negative control.

Different letters between columns mean statistical difference $(\mathrm{p}<0.05)$.

The extract of $P$. alliacea showed ovicidal activity on the eggs treated (Figure 1), regardless of plant structure, season of collection and nematode genus. The highest ovicidal activity percentage $(\mathrm{OA} \%)$ was obtained from the stem extract CRS, on average a OA\% of $91.4 \%$ was obtained against $A$. caninum. eggs at $75 \mu \mathrm{g} / \mathrm{ml}$. Regarding H. placei and cyathostomins, the OA\% was $90.3 \%$ and $90.1 \%$ at $150 \mu \mathrm{g} / \mathrm{ml}$, respectively (Table 2 ). On the other hand, the lowest $\mathrm{LC}_{50}$ and $\mathrm{LC}_{99}$ were obtained from the extracts CRS compared to the extracts collected in the dry season (CDS) $(p<0.05)$ (Table 3). The lowest $\mathrm{LC}_{50}$ and $\mathrm{LC}_{99}(\mu \mathrm{g} / \mathrm{ml})$ were obtained from the stem extract CRS compared to leaf extract. When evaluating the stem extract of $P$. alliacea against $A$. caninum eggs, a significant statistical difference $(\mathrm{p}<0.05)$ was found between $\mathrm{LC}_{50}$ and $\mathrm{LC}_{99} \mathrm{CRS}$ (33.3 and $79.5 \mu \mathrm{g} / \mathrm{ml}$ ) and the extract CDS (91.3 and $186.3 \mu \mathrm{g} / \mathrm{ml}$, respectively). In the case of $H$. placei no significant difference was observed between the seasons of collection of the P. alliacea stem. However, the $\mathrm{LC}_{50}$ obtained from CRS $(78.9 \mu \mathrm{g} / \mathrm{ml})$ was lower compared to the CDS $(92.3 \mu \mathrm{g} / \mathrm{ml})$. The $\mathrm{LC}_{50}$ of the stem CRS obtained for cyathostomins was statistically different with respect to the CDS. However, in $\mathrm{LC}_{99}$ no significant difference was found between the two collection seasons. 
Anthelmintic Activity of Petiveria alliacea, Bursera simaruba y Casearia corymbosa Collected in Two Seasons on Ancylostoma caninum, Haemonchus placei and Cyathostomins

\begin{tabular}{|c|c|c|c|c|c|c|c|}
\hline \multirow[t]{2}{*}{ Structure } & \multirow[t]{2}{*}{$\begin{array}{c}\text { Concentration } \\
(\mu \mathrm{g} / \mathrm{ml})\end{array}$} & \multicolumn{2}{|c|}{ Ancylostoma caninum } & \multicolumn{2}{|c|}{ Haemonchus placei } & \multicolumn{2}{|c|}{ Cyathostomins } \\
\hline & & Dry & Rainy & Dry & Rainy & Dry & Rainy \\
\hline \multirow{7}{*}{ Leaf } & Negative control & $0.0(0.0)$ & $1.5(0.6)$ & $1.5(1.3)$ & $2.2(1.1)$ & $5.5(0.8)$ & $5.8(3.5)$ \\
\hline & Positive control & $96.9(1.9)$ & $96.6(3.1)$ & $95.5(4.0)$ & $96.9(0.4)$ & $97.4(2.6)$ & $97.8(0.7)$ \\
\hline & 600 & $97.3(0.4)$ & $95.1(4.4)$ & $92.4(1.4)$ & $93.8(0.8)$ & $98.3(0.8)$ & $99.2(0.6)$ \\
\hline & 300 & $84.4(4.4)$ & $98.1(1.5)$ & $89.7(1.9)$ & $94.1(1.7)$ & $82.8(7.5)$ & $90.3(3.1)$ \\
\hline & 150 & $54.4(1.7)$ & $93.1(0.5)$ & $84.4(5.1)$ & $61.3(3.5)$ & $82.1(5.2)$ & $87.7(0.8)$ \\
\hline & 75 & $24.2(1.9)$ & $33.9(1.7)$ & $28.8(7.2)$ & $16.8(6.3)$ & $58.1(8.6)$ & $58.9(6.1)$ \\
\hline & 37.5 & $9.6(2.4)$ & $17.0(0.9)$ & $4.3(2.0)$ & $7.4(0.2)$ & $27.4(7.7)$ & $36.62(4.4)$ \\
\hline \multirow{7}{*}{ Stem } & Negative control & $2.9(1.3)$ & $0.9(1.5)$ & $0.4(0.1)$ & $1.4(0.2)$ & $3.0(2.1)$ & $3.9(3.5)$ \\
\hline & Positive control & $98.2(1.5)$ & $98.6(1.2)$ & $99.2(0.7)$ & $97.5(1.5)$ & $98.1(2.3)$ & $97.6(1.4)$ \\
\hline & 600 & $98.3(0.3)$ & $96.1(1.1)$ & $97.3(1.7)$ & $93.9(1.3)$ & $98.7(1.4)$ & $97.7(0.2)$ \\
\hline & 300 & $98.6(0.5)$ & $96.9(2.5)$ & $95.1(0.9)$ & $90.0(7.1)$ & $97.4(0.5)$ & $97.6(2.1)$ \\
\hline & 150 & $95.4(2.1)$ & $90.5(3.0)$ & $74.1(1.1)$ & $90.3(4.3)$ & $64.8(3.6)$ & $90.1(0.2)$ \\
\hline & 75 & $16.4(1.5)$ & $91.4(1.3)$ & $28.6(0.9)$ & $59.3(3.4)$ & $26.2(0.7)$ & $48.1(6.6)$ \\
\hline & 37.5 & $2.2(0.5)$ & 35.1 (4.7) & $1.9(0.8)$ & $12.2(2.8)$ & $18.9(6.7)$ & $32.9(4.5)$ \\
\hline
\end{tabular}

Table 2: Mean and standard deviation ( \pm ) of the percentage of ovicidal activity obtained with Petiveria alliacea extracts on eggs of Ancylostoma caninum, Haemonchus placei and cyathostomins.

\begin{tabular}{|c|c|c|c|c|c|c|c|}
\hline \multirow[t]{2}{*}{ Extract } & \multirow[t]{2}{*}{$\begin{array}{l}\text { Sea- } \\
\text { sons }\end{array}$} & \multicolumn{2}{|c|}{ Ancylostoma caninum } & \multicolumn{2}{|c|}{ Haemonchus placei } & \multicolumn{2}{|c|}{ Cyathostomins } \\
\hline & & LC 50 & LC 99 & LC 50 & LC 99 & LC 50 & LC 99 \\
\hline \multirow[t]{2}{*}{$\begin{array}{l}\text { Stem of } \\
\text { P. alliacea }\end{array}$} & Rainy & $\begin{array}{c}33.3^{\mathrm{a}} \\
(18.8-41.3) \\
\end{array}$ & $\begin{array}{c}79.5^{\mathrm{a}} \\
(70.0-98.2) \\
\end{array}$ & $\begin{array}{c}78.9^{a} \\
(66.8-93.4) \\
\end{array}$ & $\begin{array}{c}178.0^{\mathrm{a}} \\
(149.9-229.3)\end{array}$ & $\begin{array}{c}68.6^{a} \\
(31.8-96.8) \\
\end{array}$ & $\begin{array}{c}277.4^{\mathrm{a}} \\
(219.9-402.7)\end{array}$ \\
\hline & Dry & $\begin{array}{c}91.3^{\mathrm{b}} \\
(70.3-104.4)\end{array}$ & $\begin{array}{c}186.3^{b} \\
(160.8-246.0)\end{array}$ & $\begin{array}{c}92.3^{\mathrm{ab}} \\
(85.8-98.9)\end{array}$ & $\begin{array}{c}159.9^{\mathrm{ab}} \\
(148.8-174.1)\end{array}$ & $\begin{array}{c}113.6^{\mathrm{b}} \\
(98.3-129.1)\end{array}$ & $\begin{array}{c}301.8^{\mathrm{ab}} \\
(265.2-357.6)\end{array}$ \\
\hline \multirow[t]{2}{*}{$\begin{array}{l}\text { Leaf of } \\
\text { P. alliacea }\end{array}$} & Rainy & $\begin{array}{c}85.6^{\mathrm{bc}} \\
(80.9-90.1)\end{array}$ & $\begin{array}{c}154.6^{\mathrm{bc}} \\
(145.8-165.9)\end{array}$ & $\begin{array}{c}138.3^{c} \\
(122.7-158.3)\end{array}$ & $\begin{array}{c}321.4^{c} \\
(277.6-390.8)\end{array}$ & $\begin{array}{c}73.1^{\mathrm{ac}} \\
(64.1-81.5)\end{array}$ & $\begin{array}{c}230.2^{\mathrm{bc}} \\
(212.3-253.0)\end{array}$ \\
\hline & Dry & $\begin{array}{c}97.8^{\mathrm{bd}} \\
(91.0-105.1) \\
\end{array}$ & $\begin{array}{c}207.0^{\mathrm{bd}} \\
(189.3-231.1)\end{array}$ & $\begin{array}{c}129.1^{\mathrm{bcd}} \\
(94.1-180.8)\end{array}$ & $\begin{array}{c}308.1^{\text {cd }} \\
(236.0-488.6)\end{array}$ & $\begin{array}{c}89.8^{\mathrm{abcd}} \\
(47.8-158.6)\end{array}$ & $\begin{array}{c}475.1^{\mathrm{bd}} \\
(339.8-909.2)\end{array}$ \\
\hline \multirow[t]{2}{*}{$\begin{array}{l}\text { Bark of } \\
\text { B. simaruba }\end{array}$} & Rainy & $\begin{array}{c}2027.5^{\mathrm{e}} \\
(1775.1-2371.8)\end{array}$ & $\begin{array}{c}4961.4^{\mathrm{e}} \\
(4223.8-6140.9)\end{array}$ & $\begin{array}{c}4524.5^{\mathrm{e}} \\
(3718.5-8279.7) \\
\end{array}$ & $\begin{array}{c}9268.5^{\mathrm{e}} \\
(6633.9-23858.0)\end{array}$ & $\begin{array}{c}3138.4^{\mathrm{e}} \\
(2715.1-3725.2)\end{array}$ & $\begin{array}{c}6639.0^{\mathrm{e}} \\
(5578.4-8555.5) \\
\end{array}$ \\
\hline & Dry & $\begin{array}{c}3023.6^{\mathrm{f}} \\
(2662.2-3843.4)\end{array}$ & $\begin{array}{c}5293.7^{\mathrm{ef}} \\
(4735.1-6177.3)\end{array}$ & ND & ND & $\begin{array}{c}3,201.3^{\mathrm{ef}} \\
(2555.1-4319.6)\end{array}$ & $\begin{array}{c}7317.7^{\mathrm{ef}} \\
(5687.6-11198.0)\end{array}$ \\
\hline \multirow[t]{2}{*}{$\begin{array}{l}\text { Bark of } \\
\text { C. corymbosa }\end{array}$} & Rainy & $\begin{array}{c}3541.4^{\mathrm{fg}} \\
(2924.1-4372.1)\end{array}$ & $\begin{array}{c}12,670.0^{\mathrm{g}} \\
(10268.0-17080.0)\end{array}$ & $\begin{array}{c}1627.8^{\mathrm{f}} \\
(1321.5-2075.5)\end{array}$ & $\begin{array}{c}4634.3^{\mathrm{f}} \\
(3772.2-6155.7)\end{array}$ & $\begin{array}{c}5191.7^{\mathrm{fg}} \\
(4306.0-6080.6)\end{array}$ & $\begin{array}{c}12032.0^{\mathrm{fg}} \\
(10031-15658.0)\end{array}$ \\
\hline & Dry & $\begin{array}{c}4442.6^{\mathrm{ghh}} \\
(3458.9-6232.4)\end{array}$ & $\begin{array}{c}13,880.0^{\mathrm{gh}} \\
(10464.0-21978.0)\end{array}$ & $\begin{array}{c}2536.0^{\mathrm{g}} \\
(2114.5-3083.4)\end{array}$ & $\begin{array}{c}6095.8^{\mathrm{fg}} \\
(5109.1-7736.5)\end{array}$ & $\begin{array}{c}4656.1^{\mathrm{ggh}} \\
(4262.9-5337.9)\end{array}$ & $\begin{array}{c}9557.5^{\mathrm{fgh}} \\
(8045.1-12585.0)\end{array}$ \\
\hline
\end{tabular}

Table 3: Lethal concentrations at $50 \%$ and $99 \%(\mu \mathrm{g} / \mathrm{ml})$ and $95 \%$ confidence intervals obtained with extracts of Petiveria alliacea, Bursera simaruba and Casearia corymbosa on eggs of Ancylostoma caninum, Haemonchus placei and cyathostomins.

Different letters between columns mean statistical difference $(\mathrm{p}<0.05)$.

LC50: lethal concentration at 50\%; LC99: lethal concentration at 99\%. ND: Not determined 


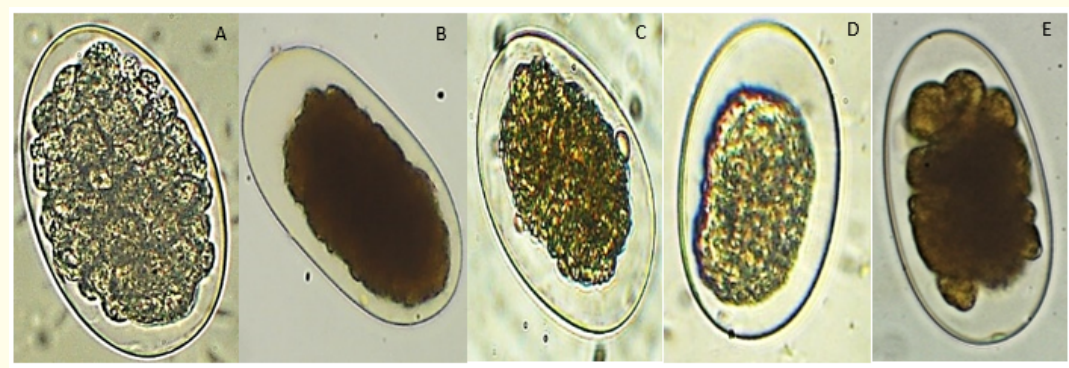

Figure 1: Effect of stem extract from Petiveria alliacea (collected in the rainy season) on nematode eggs: (A) negative control, (B) positive control, (C) Ancylostoma caninum, (D) Haemonchus placei. and (E) cyathostomins.

The species $P$. alliacea has antimicrobial, analgesic, anti-inflammatory, anticancer, antifungal, ixodicidal and antiparasitic properties $[24,25]$. The anthelmintic activity of this plant has been evaluated, individually, in previous studies against Ancylostoma spp., Haemonchus spp. and Trichostrongylus spp. reporting activity at higher concentrations (300 to $3600 \mu \mathrm{g} / \mathrm{ml}$ ) and no ovicidal effect [15-17]. Due to this fact, the technique used in the present study was modified to ensure the complete dilution of the methanolic extracts evaluated and to enhance their efficacy. This modification consisted in the addition of absolute ethanol at 5\% to the extract's solvent and the use of an ultrasonic bath. Additional measures can be used when the extracts are not homogeneously dissolved, ethanol is often used to help break down the thermodynamics of the extract components [26-28].

Arjona-Cambranes., et al. [15] evaluated the methanolic extract of the stem and leaves of P. alliacea CRS and CDS, against Ancylostoma spp. eggs at concentrations from 3600 to $300 \mu \mathrm{g} / \mathrm{ml}$, and generally, they obtained PEHI higher than $98 \%$ at $600 \mu \mathrm{g} / \mathrm{ml}$. In this study, no significant difference $(p>0.05)$ was found between the PEHI obtained $(300 \mu \mathrm{g} / \mathrm{ml})$ on the stem and leaf extracts from the rainy and dry seasons. On the other hand, this study was unable to determine the $\mathrm{LC}_{50}$ and $\mathrm{LC}_{99}$ due to the high PEHI obtained at the lowest dose $(300 \mu \mathrm{g} / \mathrm{ml})$. It was reported that the predominant effect of $P$. alliacea extract was "L1 larvae failing eclosion", because more than $80 \%$ of the eggs treated managed to develop the $\mathrm{L}_{1}$ larvae inside them, in all the concentrations evaluated. In contrast to the reports of Arjona-Cambranes., et al. [15] this study found a significant difference $(\mathrm{p}<0.05)$ with the plant parts of $P$. alliacea and the season of collection. The stem CRS obtained the best PEHI (97.8\% at $75 \mu \mathrm{g} / \mathrm{ml}$ ) against $A$. caninum, four times less concentration was required to obtain the same efficacy as Arjona-Cambranes., et al. [15]. Ovicidal effect was also observed from $91.4 \%$ to $75 \mu \mathrm{g} / \mathrm{ml}$ in contrast to the reports (larvae failing eclosion) of Arjona-Cambranes., et al. [15]. Moreover, the extracts evaluated showed higher anthelmintic activity in contrast to those reported for the ethanolic extract of Canthium mannii (PEHI of $90 \%$ at $1000 \mu \mathrm{g} / \mathrm{ml}$ ) and the ethanolic extracts of Mikania laevigata, M. glomerata and Euterpe edulis (PEHI of 21.8\%, 25.9 and 21.1\%, respectively, at 10,000 $\mu \mathrm{g} /$ ml) [26,28]. De Aguiar-Santos., et al. [29] evaluated hydroalcoholic extracts from 10 plants with insecticide properties from Brazil; however, they did not show anthelmintic activity against $A$. caninum eggs even at high concentrations $(12,500 \mu \mathrm{g} / \mathrm{ml})$.

Rosado-Aguilar., et al. [16] (abstract of a congress) evaluated the effect of the methanolic extract from the stem and leaf of $P$. alliacea CRS and CDS on eggs of Haemonchus spp. and Trichostrongylus spp. found in cattle. A $100 \%$ PEHI at a concentration of $1200 \mu \mathrm{g} / \mathrm{ml}$ was obtained for the stem CRS and the leaves CRS and CDS. No statistical difference was found between the above-mentioned extracts and the $\mathrm{LC}_{50}$ and $\mathrm{LC}_{99}$ were not reported. The effect reported on the eggs treated was the development of $\mathrm{L}_{1}$ larvae failing eclosion. In the present study, the stem CRS presented the best PEHI $(91.6 \%$ at $150 \mu \mathrm{g} / \mathrm{ml}$ ), while Rosado-Aguilar., et al. [16] required four times the dose to obtain the same efficacy ( $91.8 \%$ at $600 \mu \mathrm{g} / \mathrm{ml}$ ). In addition, an ovicidal effect against $H$. placei was observed from $90.3 \%$ to $150 \mu \mathrm{g} / \mathrm{ml}$, unlike prior studies. $H$. spp. has been one of the most studied GIN regarding the use of plant extracts as a control alternative in ruminants; however, there are scarce studies carried out in southeastern Mexico reporting plant extracts with ovicidal effect against this GIN, mainly observing the effect of " $\mathrm{L}_{1}$ larvae failing eclosion" [21,30,31]. 
Anthelmintic Activity of Petiveria alliacea, Bursera simaruba y Casearia corymbosa Collected in Two Seasons on Ancylostoma caninum, Haemonchus placei and Cyathostomins

The anthelmintic activity of $P$. alliacea on the eggs of cyathostomins was reported by Flota-Burgos., et al. [17], in that study, a PEHI higher than 98\% was obtained at $150 \mu \mathrm{g} / \mathrm{ml}$, while the best PEHI was obtained with the stem extract CRS $(97.7 \%$ at $75 \mu \mathrm{g} / \mathrm{ml})$. The results of the present study matched those reported by FlotaBurgos., et al. [17] in terms of the extract with the highest PEHI; however, the best PEHI was obtained at $150 \mu \mathrm{g} / \mathrm{ml}(94.6 \%)$ and at $75 \mu \mathrm{g} / \mathrm{ml}$ the PEHI dropped to $56.8 \%$. Flota-Burgos., et al. [17], reported $\mathrm{L}_{1}$ larvae failing eclosion, contrary to the ovicidal effect of $90.1 \%$ at $150 \mu \mathrm{g} / \mathrm{ml}$ observed in the present study. Studies on the anthelmintic activity of plants such as Acacia baileyana, A. melanoxylon, A. podalyriifolia, Alectryon oleifolius, Duboisia hopwodii, Eucalyptus gomphocephala and Santalum spicatum against these nematodes have reported that a higher concentration $(1400 \mu \mathrm{g} / \mathrm{ml})$ is required to obtain a PEHI of $100 \%$ similar to $P$. alliacea [22,32]. In the present study it was observed that $P$. alliacea extract caused an ovicidal effect on treated eggs of the three GIN genera studied. The ovicidal effect refers to the inhibition of larval development, so the treated eggs remain in the morula phase and do not develop into larvae $\mathrm{L}_{1}$. This effect could be attributed to a more homogeneous dilution of the P. alliacea extract with the addition of $5 \%$ of absolute ethanol and the use of the ultrasonic bath, which probably allowed the secondary compounds responsible for the anthelmintic activity to penetrate in greater proportion the membrane that covers the eggs affecting the development of the morula causing the ovicidal effect not present in previous studies with the same nematodes $[17,33]$. Chagas [34] mentions that it is important to choose a suitable solvent for the in vitro evaluation of the plant extracts of interest, since an inadequate one may cause toxicity to the GIN eggs under evaluation, generating false positives or masking the true effect of the extract. The effect of a potent extract may be underestimated or ruled out by factors outside the extract itself (poor dilution, inadequate techniques, unsuitable solvents), thus losing a potential source for the development of new control alternatives [35].

The ovicidal effect observed with P. alliacea extract is similar to that caused by thiabendazole, therefore, when using this extract, it is likely to obtain efficacies and effects similar to anthelmintics currently available on the market and that these GINs have been reported as resistant [36].

\section{Bursera simaruba extracts}

B. simaruba extract CRS showed significant anthelmintic effect on A. caninum eggs. (95.4\% PEHI at $3600 \mu \mathrm{g} / \mathrm{ml}$ ) and showed no significant difference with respect to the positive control $(p>0.05)$.
On the other hand, the anthelmintic activity (PEHI) of this extract against H. placei $(25.4 \%$ to $3600 \mu \mathrm{g} / \mathrm{ml})$ and cyathostomins $(56.4 \%$ to $3600 \mu \mathrm{g} / \mathrm{ml}$ ) was low (Table 4). Using the bark extract of $B$. simaruba, it was observed that the $\mathrm{LC}_{50}$ and $\mathrm{LC}_{99}$ were lower in the collection in the rainy season. Statistically, the LC50 of both collections was found to be different against eggs of $A$. caninum, while no difference was found between the $\mathrm{LC}_{50}$ and $\mathrm{LC}_{99}$ of both collection seasons against cyathostomin eggs. Due to the low PEHI against H. placei eggs obtained from B. simaruba extract CDS, the $\mathrm{LC}_{50}$ and $\mathrm{LC}_{99}$ could not be determined in this study (Table 3). On the other hand, the extracts to $B$. simaruba caused the effect of " $\mathrm{L}_{1}$ larvae failing eclosion" (LFE) on the eggs treated (Figure 2), regardless of the season of collection and the genus of nematode against which they were evaluated. The highest percentages of LFE were obtained from the extracts CRS compared to CDS. The B. simaruba extract CRS showed, on average, 95.1\%, 23.7\% and 51.4\% LFE against $A$. caninum, $H$. placei and cyathostomins, respectively, at the concentration of $3600 \mu \mathrm{g} / \mathrm{ml}$.

B. simaruba bark has antifungal, antidiarrheal, anti-inflammatory, analgesic, antipyretic and antispasmodic properties [37]. Other species of the genus Bursera have antiparasitic activity against Mexican Leishmania, Entamoeba histolytica and infective larvae of $H$. contortus [38-40]. In particular, the anthelmintic activity of B. simaruba against nematode eggs has been scarcely studied. Arjona-Cambranes., et al. [15] found a PEHI of less than $10 \%$ when evaluating the methanolic extract of $B$. simaruba against $A$. caninum $(3600 \mu \mathrm{g} / \mathrm{ml})$, they attributed the low activity to the poor solubility of the extract. Due to the complete dilution of the extract, in the present study it was obtained a PEHI of up to $95.4 \%$ and $56.3 \%$ at the dose of $3600 \mu \mathrm{g} / \mathrm{ml}$ against $A$. caninum and cyathostomins, respectively. Despite the fact that the nematodes evaluated belong to the order Strongylida, the eggs of the nematodes studied may have structural differences that would explain the different susceptibility to the metabolites present in the extracts studied [41,42]. It was observed that the $B$. simaruba extract presented the effect of $\mathrm{L}_{1}$ that failed eclosion in the three evaluated GIN genera, coinciding with the reports of a study conducted against $A$. caninum [15]. This effect suggests that the metabolites responsible for the activity may interfere with the permeability of the membrane that covers the egg, preventing changes that are necessary for the hatching process, inhibiting the enzymes responsible for hatching or competing with the receptors for hatching factors present in this structure of the egg [20]. 
Anthelmintic Activity of Petiveria alliacea, Bursera simaruba y Casearia corymbosa Collected in Two Seasons on Ancylostoma caninum, Haemonchus placei and Cyathostomins

\begin{tabular}{|c|c|c|c|c|c|}
\hline Extract & Season & $\begin{array}{c}\text { Concentration } \\
(\mu \mathrm{g} / \mathrm{ml})\end{array}$ & $\begin{array}{l}\text { Ancylostoma } \\
\text { caninum }\end{array}$ & $\begin{array}{l}\text { Haemonchus } \\
\text { placei }\end{array}$ & Cyathostomins \\
\hline \multirow{14}{*}{ Bursera simaruba } & \multirow{7}{*}{ Dry } & Negative control & $1.1(0.7)^{\mathrm{a}}$ & $2.4(1.0)^{\mathrm{a}}$ & $8.9(5.3)^{\mathrm{a}}$ \\
\hline & & Positive control & $98.9(1.3)^{* b}$ & $97.2(0.8)^{* \mathrm{~b}}$ & $98.9(0.3)^{* b}$ \\
\hline & & 3600 & $79.8(7.0)^{* c}$ & $2.3(2.7)^{\mathrm{c}}$ & $48.1(2.1)^{\mathrm{c}}$ \\
\hline & & 2400 & $21.6(3.0)^{* d}$ & $2.4(1.3)^{\mathrm{d}}$ & $39.9(1.2)^{\mathrm{d}}$ \\
\hline & & 1200 & $8.5(2.1)^{* \mathrm{e}}$ & $2.9(1.5)^{\mathrm{e}}$ & $25.1(3.0)^{* e}$ \\
\hline & & 600 & $1.3(0.6)^{\mathrm{f}}$ & $2.8(0.6)^{f}$ & $17.1(2.3)^{* \mathrm{f}}$ \\
\hline & & 300 & $1.0(1.1)^{\mathrm{g}}$ & $2.8(1.6)^{\mathrm{g}}$ & $7.1(1.3)^{\mathrm{g}}$ \\
\hline & \multirow{7}{*}{ Rainy } & Negative control & $3.1(1.7)^{\mathrm{a}}$ & $3.0(2.7)^{\mathrm{a}}$ & $8.3(3.1)^{\mathrm{a}}$ \\
\hline & & Positive control & $99.7(0.2)^{* b}$ & $95.7(1.8)^{* \mathrm{~b}}$ & $100.0(0.0)^{* \mathrm{~b}}$ \\
\hline & & 3600 & $95.4(3.7)^{* b}$ & $25.4(3.5)^{* c}$ & $56.3(4.1)^{* c}$ \\
\hline & & 2400 & $44.1(2.7)^{* c}$ & $25.2(3.7)^{* d}$ & $35.7(7.8)^{* d}$ \\
\hline & & 1200 & $27.0(5.8)^{* \mathrm{~d}}$ & $2.1(0.6)^{\mathrm{e}}$ & $21.4(0.9)^{* \mathrm{e}}$ \\
\hline & & 600 & $15.8(2.4)^{* \mathrm{e}}$ & $5.0(4.5)^{\mathrm{f}}$ & $7.5(1.9)^{\mathrm{f}}$ \\
\hline & & 300 & $6.4(2.0)^{\mathrm{f}}$ & $3.4(1.1)^{\mathrm{g}}$ & $3.0(0.6)^{g}$ \\
\hline
\end{tabular}

Table 4: Mean and standard deviation ( \pm ) of the percentage of egg hatch inhibition obtained with Bursera simaruba extracts on eggs of Ancylostoma caninum, Haemonchus placei and cyathostomins.

* Significant difference with negative control.

Different letters between columns mean statistical difference $(p<0.05)$.

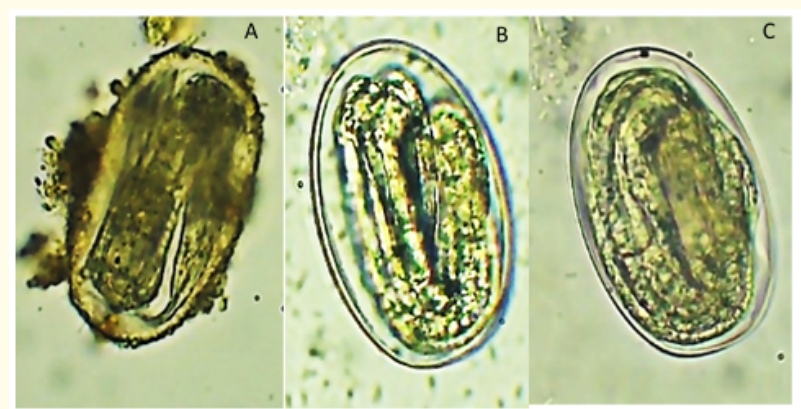

Figure 2: Effect caused by Bursera simaruba on the development of L1 larvae within treated eggs that failed to hatch, (A) Ancylostoma caninum (B) Haemonchus placei and (C) cyathostomins.

\section{Casearia corymbosa extracts}

In the case of $C$. corymbosa extract CRS (Table 5) a moderate anthelmintic activity was obtained on $H$. placei eggs. $(74.0 \%$ to $3600 \mu \mathrm{g} / \mathrm{ml}$ ) compared to the results obtained against the eggs of
A. caninum and cyathostomins $(55.1 \%$ and $56.6 \%$ at the same concentration, respectively). The effect of $C$. corymbosa extracts was " $\mathrm{L}_{1}$ larvae failing eclosion" (LFE) on the eggs treated (Figure 3 ). The extract of $C$. corymbosa of CRS obtained, on average, $54.3 \%, 60.8 \%$ and $30.4 \%$ of LFE against $A$. caninum, $H$. placei and cyathostomins, respectively, at the concentration of $3600 \mu \mathrm{g} / \mathrm{ml}$. In addition to the effect caused against the eggs, the extract of $C$. corymbosa CRS $(1200 \mu \mathrm{g} / \mathrm{ml})$ caused damage to the internal structures in $100 \%$ of the larvae that were able to hatch in comparison with the larvae that emerged from the negative control (Figure 4, 5 and 6). Additionally, no significant difference was found between the $\mathrm{LC}_{50}$ and $\mathrm{LC}_{99}$ of the different collection seasons when evaluating the bark extract of $C$. corymbosa against eggs of $A$. caninum and cyathostomins. In the evaluation against $H$. placei eggs, a difference was found between the $\mathrm{LC}_{50}$ obtained in CRS $(1627.8 \mu \mathrm{g} / \mathrm{ml})$ compared with CDS $(2536.0 \mu \mathrm{g} / \mathrm{ml})$; however, there was no significant difference in the $\mathrm{LC}_{99}$ of both collections (Table 3 ). 
Anthelmintic Activity of Petiveria alliacea, Bursera simaruba y Casearia corymbosa Collected in Two Seasons on Ancylostoma caninum, Haemonchus placei and Cyathostomins

\begin{tabular}{|c|c|c|c|c|c|}
\hline Extract & Season & $\begin{array}{l}\text { Concentration } \\
(\mu \mathrm{g} / \mathrm{ml})\end{array}$ & $\begin{array}{c}\text { Ancylostoma } \\
\text { caninum }\end{array}$ & $\begin{array}{c}\text { Haemonchus } \\
\text { placei }\end{array}$ & Cyathostomins \\
\hline \multirow{14}{*}{ Casearia corymbosa } & \multirow{7}{*}{ Dry } & Negative control & $10.0(1.4)^{\mathrm{a}}$ & $4.6(1.2)^{\mathrm{a}}$ & $8.9(5.3)^{\mathrm{a}}$ \\
\hline & & Positive control & $95.8(2.1)^{* b}$ & $100.0(0.0)^{* \mathrm{~b}}$ & $98.9(0.3)^{* b}$ \\
\hline & & 3600 & $45.0(1.3)^{* \mathrm{c}}$ & $65.4(1.3)^{* c}$ & $48.1(2.1)^{c}$ \\
\hline & & 2400 & $44.0(0.6)^{* d}$ & $61.6(4.2)^{* d}$ & $45.7(0.2)^{\mathrm{d}}$ \\
\hline & & 1200 & $38.7(1.7)^{* \mathrm{e}}$ & $31.7(5.6)^{* \mathrm{e}}$ & $28.8(5.3)^{* \mathrm{e}}$ \\
\hline & & 600 & $26.1(2.6)^{* \mathrm{f}}$ & $18.9(6.1)^{* \mathrm{f}}$ & $22.1(3.9)^{* \mathrm{f}}$ \\
\hline & & 300 & $22.3(2.0)^{* g}$ & $13.0(3.6)^{* g}$ & $20.5(2.8)^{* g}$ \\
\hline & \multirow{7}{*}{ Rainy } & Negative control & $9.2(1.6)^{a}$ & $3.5(3.0)^{\mathrm{a}}$ & $8.3(3.1)^{a}$ \\
\hline & & Positive control & $95.3(2.7)^{* b}$ & $100.0(0.0)^{* b}$ & $100.0(0.0)^{* b}$ \\
\hline & & 3600 & $55.1(0.8)^{* c}$ & $74.0(4.0)^{* c}$ & $56.4(4.5)^{* c}$ \\
\hline & & 2400 & $46.0(1.3)^{* d}$ & $73.7(6.6)^{* d}$ & $35.7(7.8)^{* d}$ \\
\hline & & 1200 & $42.1(3.1)^{* e}$ & $66.6(4.0)^{* e}$ & $21.4(0.9)^{* e}$ \\
\hline & & 600 & $31.2(1.5)^{* \mathrm{f}}$ & $23.9(4.4)^{* \mathrm{f}}$ & $7.5(1.9)^{* \mathrm{f}}$ \\
\hline & & 300 & $28.3(2.3)^{* g}$ & $19.3(3.6)^{* g}$ & $3.0(0.6)^{\mathrm{g}}$ \\
\hline
\end{tabular}

Table 5: Mean and standard deviation ( \pm ) of percentage of egg hatch inhibition obtained with Casearia corymbosa extracts on eggs of Ancylostoma caninum, Haemonchus placei and cyathostomins.

* Significant difference with negative control.

Different letters between columns mean statistical difference $(p<0.05)$.

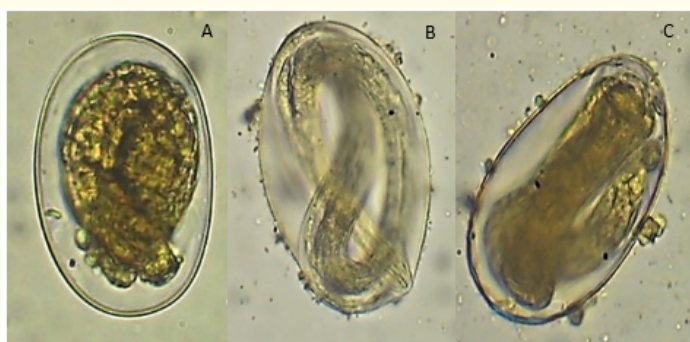

Figure 3: Effect caused by Casearia corymbosa on the formation of $\mathrm{L}_{1}$ larvae within treated eggs that failed to hatch (A) Ancylostoma caninum, (B) Haemonchus placei and (C) cyathostomins.

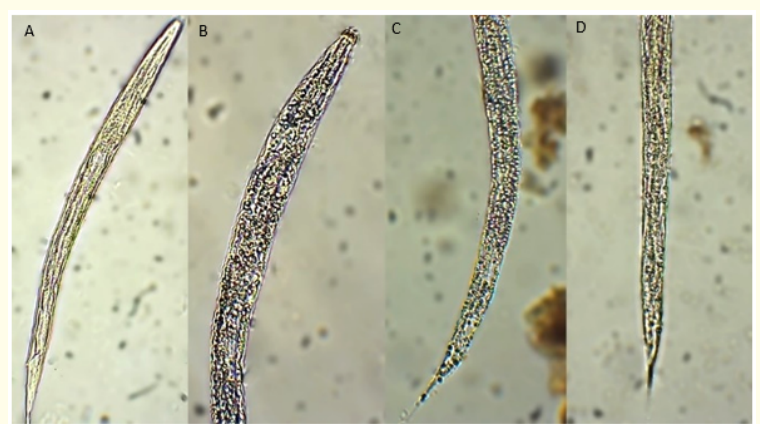

Figure 4: $\mathrm{L}_{1}$ larvae of Ancylostoma caninum, treated with C. corymbosa (40x): (A) control; anterior part (B) and posterior part (C and $D$ ) of the larvae with degeneration and vacuolization of the esophagus and intestinal cells.

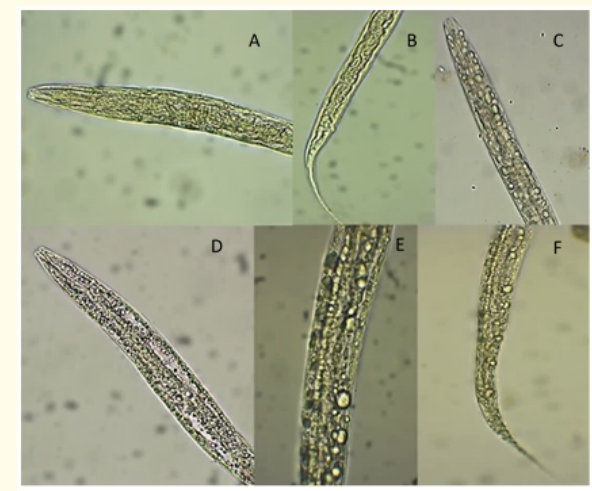

Figure 5: Effect of $C$. corymbosa on $\mathrm{L}_{1}$ larvae of Haemonchus placei (40x): Negative control larvae (A and B); anterior part (C and D) and posterior ( $\mathrm{E}$ and $\mathrm{F}$ ) of larvae with vacuolization of the esophagus and intestinal cells.

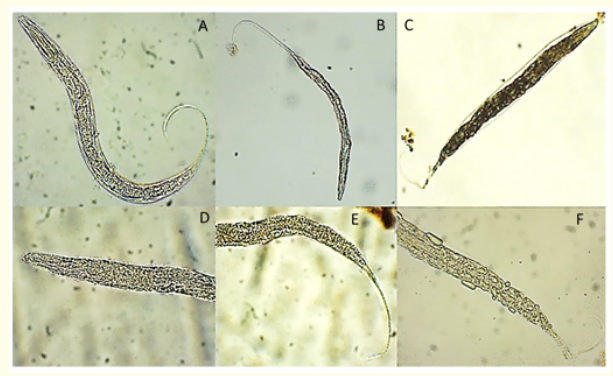

Figure 6: Damage caused by C. corymbosa in cyathostomin larvae: (A) negative control at 40x; ( $B$ and $C$ ) degeneration of the esophagus, intestinal cells and cuticle seen at 10x; vacuolization and degeneration of esophagus (D) and intestinal cells (E and F) seen at $40 x$. 
Anthelmintic Activity of Petiveria alliacea, Bursera simaruba y Casearia corymbosa Collected in Two Seasons on Ancylostoma caninum, Haemonchus placei and Cyathostomins

Among the biological properties of $C$. corymbosa, there are reports of anti-cancer, anti-inflammatory, antitussive and antibacterial effects [43,44]. Arjona-Cambranes., et al. [15] evaluated the bark extract of $C$. corymbosa collected in the rainy season and obtained a 34.5\% (3600 $\mu \mathrm{g} / \mathrm{ml})$ PEHI in Ancylostoma spp. eggs, compared to this work, in which it was obtained a PEHI > 50\% in the eggs of the three evaluated GINs. The ethanolic extract of Casearia acuelata was evaluated against $H$. placei eggs obtaining low PEHI even using higher concentrations than this study: $11.3 \%, 7.3 \%$ and $10.2 \%$ at $1000,10,000$ and $50,000 \mu \mathrm{g} / \mathrm{ml}$, respectively [45]. There is no information about the anthelmintic potential of this plant or others of its genus against cyathostomins; in the present work a moderate anthelmintic effect was observed (56.4\%) at lower concentrations than those reported in previous studies with other nematodes. The effect of the $C$. corymbosa extract on the three nematodes was $L_{1}$ larvae failing eclosion, an explanation for this has already been described above as for the B. simaruba extract.

Despite not having a high anthelmintic effect on the treated eggs, from the concentration of $1200 \mu \mathrm{g} / \mathrm{ml}$, the extract of $C$. corymbosa caused morphological damage in $100 \%$ of $\mathrm{L}_{1}$ larvae that managed to hatch and that were not observed in larvae that hatched in the negative controls. Degeneration of intestinal cells was observed, similar to those reported in $\mathrm{L}_{1}$ larvae of $H$. contortus exposed to secondary metabolites present in the extracts of Acacia pennatula and Onobrychis viciifolia, as well as the presence of numerous vacuoles in the internal structures $[21,46]$.

Secondary metabolites involved in the anthelmintic activity of plant extracts

Secondary metabolites reported in P. alliacea include alkaloids, coumarins, saponins, flavonoids, steroids, polyphenols, tannins, triterpenes and sulfur compounds, with different concentrations in the leaves and stem $[47,48]$. The presence of sulphur compounds stands out as being responsible for their antimicrobial, anti-cancer and anti-fungal activity [49-52]. Arceo-Medina., et al. [24] also identified sulphur compounds (dibenzyl disulphide and dibenzyltrisulphide) as responsible for the acaricidal activity of $P$. alliacea against Rhipicephalus microplus. Kubec and Musah [47] mention that the concentration of sulphur compounds is approximately four times higher in the stem than in the leaves of the plant. In addition, an essential oil called petiverin, has been reported to be found in higher concentrations in the stem than in the leaf $[47,48]$. The aforementioned could explain the differences observed in the PEHI and LC of the stem and leaf extracts.
Only the $\mathrm{LC}_{50}$ of $B$. simaruba CRS, evaluated against $A$. spp. showed significant difference when compared to the $\mathrm{LC}_{50} \mathrm{CDS}$. In the evaluation against $H$. placei. and cyathostomins no differences were found between the $\mathrm{LC}_{50}$ and $\mathrm{LC}_{99}$ of the different collection seasons. In the genus Bursera, the presence of essential oils has been reported as well as triterpenes, steroids, bilignans, lignans, alkaloids, saponins, quinones and flavonoids, particularly in the plant resin [53,54]. Maldini., et al. [53] mention that in the bark of B. simaruba there are abundant phenolic and lignan-derived compounds, which are related to antimicrobial, fungistatic and insecticidal activity.

On the other hand, only $\mathrm{LC}_{50}$ of $C$. corymbosa CRS proved to be statistically significant when evaluated against $H$. placei. Terpenoids, particularly clerodal dipertenoids, are the predominant secondary metabolites in the genus Casearia, as well as phenylpropanoids, sesquiterpenoids, flavonoids, steroids and essential oils [55-57]. Antiparasitic activity of the genus Casearia against Trypanosoma cruzi, Leishmania donovani and Plasmodium falciparum has been demonstrated with promising results, attributed to the presence of clerodane-type dipertenoids. It is important to mention that these secondary compounds are significantly present in the bark, so they could be responsible for the observed anthelmintic activity [58-61].

The significant difference in anthelmintic activity (PEHI and LC) observed in this study when comparing extracts CRS versus CDS may be explained by the seasonal variation that influences the amount, composition and expression of the secondary metabolites present in the plants evaluated [62,63]. Several studies have found a higher concentration of secondary metabolites with biological activity in the months corresponding to the rainy season compared to the dry season $[64,65]$. Kubec and Musah [47] mention that the content of secondary compounds is variable and depends on several factors including the weather and the date of collection. Arceo-Medina., et al. [24] reported higher acaricidal activity with P. alliacea extracts collected in the dry season, which was different from the results of this study. There are no studies on the seasonal variability of secondary compounds present in $B$. simaruba and $C$. corymbosa.

Extracts from the stem of P. alliacea and the bark of B. simaru$b a$, CRS, have been shown to possess a broad spectrum of activity against eggs of the three GIN genera studied, so future studies should focus on identifying the secondary metabolites responsible 
Anthelmintic Activity of Petiveria alliacea, Bursera simaruba y Casearia corymbosa Collected in Two Seasons on Ancylostoma caninum, Haemonchus placei and Cyathostomins

for their anthelmintic activity. Concerning the $C$. corymbosa bark extract and due to the effect observed on larvae of the evaluated genera, in addition to the identification of secondary active metabolites, it is required to evaluate it with more appropriate tests on larval stages, such as the nematode larval mortality assay, larval migration inhibition test or larval exsheathment inhibition assay $[66,67]$. Furthermore, in vivo studies are needed to establish the pharmacodynamics and pharmacokinetics of the active compounds found in the extracts with anthelmintic activity, as well as the appropriate doses and to ratify their broad spectrum of activity under field conditions.

\section{Conclusion}

The methanolic extracts of $P$. alliacea, $B$. simaruba and C. corymbosa collected in rainy season showed the highest anthelmintic activity on eggs of A. caninum, H. placei and cyathostomins. The stem of $P$. alliacea CRS has high ovicidal activity on the three nematodes, representing a potential alternative control with a broad spectrum against the main nematodes of domestic animals.

\section{Acknowledgements}

The authors express their gratitude to CONACYT for the financial support for this work (grant No. CB-2012-01-178216). Likewise, Gabriela Janett Flota-Burgos gratefully acknowledges CONACYT for the scholarship granted to carry out her doctoral studies.

\section{Conflict of Interest}

None.

\section{Bibliography}

1. Little S E., et al. "Prevalence of intestinal parasites in pet dogs in the United States". Veterinary Parasitology 166 (2009): 4452.

2. Gilleard J S. "Haemonchus contortus as a paradigm and model to study anthelmintic drug resistance". Parasitology 140.12 (2013): 1506-1522.

3. Matthews J B. "Anthelmintic resistance in equine nematodes". International Journal of Parasitology: Drugs and Drug Resistance 4.3 (2014): 310-315.

4. Coles G C., et al. "The detection of anthelmintic resistance in nematodes of veterinary importance". Veterinary Parasitology 135 (2006): 167-185.

5. Geurden T., et al. "Anthelmintic resistance to ivermectin and moxidectin in gastrointestinal nematodes of cattle in Europe". International Journal of Parasitology: Drugs and Drug Resistance 5.3 (2015): 163-171.
6. Kopp S R., et al. "Application of in vitro anthelmintic sensitivity assays to canine parasitology: Detecting resitance to pyrantel in Ancylostoma caninum". Veterinary Parasitology 152 (2008): 284-293.

7. Kitchen S., et al. "Isolation and characterization of a naturally occurring multidrug-resistance strain of the canine hookworm, Ancylostoma caninum". International Journal for Parasitology 49 (2019): 397-406.

8. Mungube E O., et al. "Prevelance of multiple resistant Haemonchus contortus and Ostertagia species in goats and cattle in Machakos, Eastern Kenya". Livestock Research for Rural Development 27 (2015).

9. Ramos F., et al. "Anthelmintic resistance in gastrointestinal nematodes of beef cattle in the state of Rio Grande do Sul, Brazil". International Journal of Parasitology: Drugs and Drug Resistance. 6.1 (2016): 93-101.

10. Jaeger L H and Carvalho-Costa F A. "Status of benzimidazole resistance in intestinal nematode populations of livestock in Brazil: a systematic review". BMC Veterinary Research 13.1 (2017): 358.

11. Relf V E., et al. "Anthelmintic efficacy on UK Thoroughbred stud farms". International Journal for Parasitology 44.8 (2014): 507-514.

12. Daniels S P and Proudman C J. "Shortened egg reappearance after ivermectin or moxidectin use in horses in the UK". The Veterinary Journal 218 (2016): 36-39.

13. Bellaw J L., et al. "Anthelmintic therapy of equine cyathostomin nematodes - larvicidal efficacy, egg reappearance period, and drug resistance". International Journal for Parasitology 48.2 (2018): 97-105.

14. Hoste H., et al. "Tannin containing legumes as a model for nutraceuticals against digestive parasites in livestock". Veterinary Parasitology 212 (2015): 5-17.

15. Arjona-Cambranes K A., et al. "Actividad antihelmíntica in vitro de extractos vegetales contra huevos de Ancylostoma spp. de perros". Ciencia y Agricultura 13.2 (2016): 76.

16. Rosado-Aguilar J A., et al. "Actividad antihelmíntica de extractos metanólicos contra huevos del orden Strongylida de bovinos". Ciencia y Agricultura 13.2 (2016): 78.

17. Flota-Burgos G J., et al. "Anthelminthic activity of methanol extracts of Diospyros anisandra and Petiveria alliacea on cyathostomin (Nematoda: Cyathostominae) larval development and egg hatching". Veterinary Parasitology 248 (2017): 74-79.

18. Instituto Nacional de Estadística y Geografía, "Clima en Yucatán”. (2019). 
19. Rosado-Aguilar J A., et al. "Acaricidal activity of extracts from Petiveria alliacea (Phytolaccaceae) against the cattle tick, Rhipicephalus (Boophilus) microplus (Acari: ixodidae)". Veterinary Parasitology 168 (2010): 299-303.

20. Vargas-Magaña J J., et al. "Anthelmintic activity of acetone-water extracts against Haemonchus contortus eggs: Interactions between tannins and other plant secondary compounds". Veterinay Parasitology 206 (2014): 322-327.

21. Chan-Pérez J I., et al. "In vitro susceptibility of ten Haemonchus contortus isolates from different geographical origins towards acetone: water extracts of two tannin rich plants". Veterinary Parasitology 217 (2016): 53-60.

22. Peachey L E., et al. "An evidence-based approach to the evaluation of ethnoveterinary medicines against strongyle nematodes of equids". Veterinary Parasitology 210 (2015): 40-52.

23. Robertson J L., et al. "POLO: A User's Guide to Probit or Logit Analysis". Pacific Southwest Forest and Range Experiment Station, Bekerley, California (1980).

24. Arceo-Medina G., et al. "Effect of season and sampling location on acaricidal activity of Petiveria alliacea on larvae Rhipicephalus microplus resistant to acaricides". Journal of Veterinary Medicine and Allied Science 1.1 (2017): 1-22.

25. Silva J P., et al. "Antimicrobial and anticancer potential of Petiveria alliacea L. (Herb to "Tame the Master"): A review". Pharmacognosy Reviews 12 (2018): 85-93.

26. Wabo Poné J., et al. "In vitro activity of ethanol, cold water and hot water extracts of the bark of Canthium mannii (Rubiaceae) stem on Ancylostoma caninum eggs". East and Central African Journal of Pharmaceutical Science 9 (2006): 14-28.

27. Liu Z. "Preparation of botanical samples for biomedical research". Endocrine, Metabolic \& Immune Disorders - Drug Targets 8.2 (2008): 112-121. https://www.ncbi.nlm.nih.gov/ pmc/articles/PMC3936020/

28. Tonini Zamprogno T., et al. "Activity of Euterpe edulis Martius, Mikania glomerata Spreng, and Mikania laevigata Schultz Bip. Extracts on gastrointestinal nematodes Toxocara canis and Ancylostoma caninum. Archives of Clinical Infectious Diseases 10.3 (2015): e27495.

29. De Aguiar Santos I., et al. "Evaluation of ovicidal and larvicidal activity of ten plant extracts against Ancylostoma spp." Revista de Patología Tropical 42.2 (2013): 209-216.

30. Castañeda-Ramírez, G S., et al. "An in vitro approach to evaluate the nutraceutical value of plant foliage against Haemonchus contortus". Parasitology Research 117.12 (2018): 3979-3991.
31. Castañeda-Ramírez G S. "Effects of different extracts of three Anona species on egg-hatching processes of Haemonchus contortus". Journal of Helmintology $94 . e 77$ (2020): 1-8.

32. Payne S E., et al. "Australians plants show anthelmintic activity toward equine cyathostomins in vitro". Veterinary Parasitology 1 (2013): 153-160.

33. Souza M., et al. "Anthelmintic acetogenin from Annona Squamosa L. Seed". Anais da Academia Brasileira de Ciências 80 (2008): 271-277.

34. Chagas A C. "Medicinal plant extracts and nematode control". CAB Reviews 10.8 (2015): 1-8.

35. D'Angelo F., et al. "Evaluation of ovicidal and larvicidal activities of methylene chloride extract of Annona senegalensis (Annonaceae) stem bark on Heligmosomoides bakeri (Nematoda, Heligmosomatidae)". Global Journal of Science Frontier Research 14.2 (2014): 21-39.

36. Mendoza-Patiño N. "Farmacología médica". MX: Editorial Médica Panamericana. Ciudad de México, México (2008).

37. López-Aroche U., et al. "In vitro nematicidal effects of medicinal plants from the Sierra de Huautla, Biosphere Reserve, Morelos, Mexico against Haemonchus contortus infective larvae". Journal of Helmintology 82.1(2008): 25-31.

38. Estrada Faggioli E. "Bursera simaruba, el árbol sagrado". Bioma. 1.7 (2013): 7-11.

39. Rosas-Arreguín P., et al. "Bursera fagaroides, effect of an ethanolic extract on ornithine decarboxylase (ODC) activity in vitro and on the growth of Entamoeba histolytica". Experimental Parasitology 119.3 (2008): 398-402.

40. Nieto-Yañez 0 J., et al. "In vivo and in vitro antileishmanial effects of methanolic extract from bark of Bursera aptera". African Journal of Traditional, Complementary and Alternative Medicines 14.2 (2008): 188-197.

41. Bird A F. and Bird J. "The structure of nematodes". Academic Press Inc. San Diego, California (1991)

42. Mansfield L S., et al. "Characterization of the eggshell of Haemonchus contortus--I. Structural components". Comparative Biochemistry and Physiology B103.3 (1992): 681-686.

43. Arellano Rodriguez J., et al. "Nomenclatura, Forma de Vida, Uso, Manejo y Distribución de las Especies Vegetales de la Península de Yucatán". Universidad Autónoma de Yucatán Mérida, Yucatán (2003).

44. Vila-Luna M L., et al. "Cytotoxic activity of casearborin c isolated from Casearia corymbosa". Journal of Mexican Chemical Society 62.3 (2018): 24-28. 
Anthelmintic Activity of Petiveria alliacea, Bursera simaruba y Casearia corymbosa Collected in Two Seasons on Ancylostoma caninum, Haemonchus placei and Cyathostomins

45. Borges D G L., et al. "Discovery of potential ovicidal natural products using metabolomics". PLoS One 14.1 (2019): e0211237.

46. Brunet S., et al. "Ultrastructural changes in the third-stage, infective larvae of ruminant nematodes treated with sainfoin (Onobrychis viciifolia) extract". Parasitology International 60.4 (2011): 419-424.

47. Kubec R. and Musah R A. "Cysteine sulfoxide derivatives in Petiveria alliacea". Phytochemistry 58.6 (2001): 981-985.

48. Luz D A., et al. "Ethnobotany, phytochemistry and neuropharmacological effects of Petiveria alliacea L. (Phytolaccaceae): A review". Journal of Ethnopharmacology 185 (2016): 182-201.

49. Benevides P J., et al. "Antifungal polysulphides from Petiveria alliacea L". Phytochemistry 57.5 (2001): 743-747.

50. Rosner H., et al. "Disassembly of microtubules and inhibition of neurite outgrowth, neuroblastoma cell proliferation, and MAPkinase tyrosine dephosphorylation by dibenzil trisulphide". Biochimica et Biophysica Acta 1540.2 (2001): 166-177.

51. Kim S., et al. "Antibacterial and antifungal activity of sulfurcontaining compounds from Petiveria alliacea L". Journal of Ethnofharmacology 104 (2006): 188-192.

52. Sariego-Frómeta S., et al. "Petiveria alliacea L.: distintas condiciones experimentales en la elaboración de extractos con actividad antimicrobiana". Revista QuímicaViva 3.12 (2013): 274-287.

53. Maldini M., et al, "Phenolic compounds from Bursera simaruba Sarg. bark: phytochemical investigation and quantitative analysis by tandem mass spectrometry". Phytochemistry 70 (2009): 641-649.

54. Beltrán D., et al. "Tamizaje fitoquímico preliminar de especies de pantas promisorias de la costa atlántica colombiana”. Revista Cubana de Plantas Medicinales 18 (2013): 619-631.

55. Mosaddick M A., et al. "Clerodane diterpenos from the stems of Casearia grewiifolia var. gelonioides (Flacourtiaceae/Salicaceae sensu lato)". Biochemical Systematics and Ecology 35 (2007): 631-633.

56. Ferreira P M P., et al. "Folk uses and pharmacological properties of Casearia sylvestris: a medicinal review". Anais da Academia Brasileria de Ciências 83.4 (2011): 1373-1384.

57. Xia L., et al. "The genus Casearia: a phytochemical and pharmacological overview". Phytochemistry Reviews 14 (2014): 99135.

58. Espindola L S., et al. "Trypanocidal activity of a new diterpene from Casearia sylvestris var. Lingua". Planta Med 70.11 (2004): 1093-1095.
59. Kanokmedhakul S., et al. "New bioactive clerodane diterpenoids from the bark of Casearia grewiifolia". Journal of Natural Products 68.2 (2005): 183-188.

60. Mesquita M L., et al. "Antileishmanial and trypanocidal activity of Brazilian Cerrado plants". Memórias do Instituto Oswaldo Cruz 100.7 (2005): 783-787.

61. Mesquita M L., et al. "In vitro antiplasmodial activity of Brazilian Cerrado plants used as traditional remedies". Journal of Ethnopharmacology 110.1 (2007): 165-170.

62. Castelo A V M., et al. "Seasonal Variation in the Yield and the Chemical Composition of Essential Oils from Two Brazilian Native Arbustive Species". Journal of Applied Sciences 12.8 (2012): 753-760.

63. Ben Jemâa J M., et al. "Seasonal variations in chemical composition and fumigant activity of five Eucalyptus essential oils against three moth pests of stored dates in Tunisia". Journal of Stored Products Research 48 (2012): 61-67.

64. Valares Masa C. "Variación del metabolismo secundario en plantas debida al genotipo y al ambiente”. Diss Universidad de Extremadura. Badajoz, España (2011).

65. Anese S., et al. "Seasonal variation in phytotoxicity of Drimys brasiliensis Miers”. Idesia 32.3 (2014): 109-116.

66. Zangueu C B., et al. "In vitro effects of aqueous extract from Maytenus senegalensis (Lam.) Exell stem bark on egg hatching, larval migration and adult worms of Haemonchus contortus". BMC Veterinay Research 14.1 (2018): 147.

67. Kumar M U., et al. "In vitro effect of botanicals against rice root knot nematode Meloidogyne graminícola". Journal of Pharmacognosy and Phytochemistry 8.4 (2019): 1027-1030.

\section{Assets from publication with us}

- Prompt Acknowledgement after receiving the article

- Thorough Double blinded peer review

- Rapid Publication

- Issue of Publication Certificate

- High visibility of your Published work

Website: www.actascientific.com/

Submit Article: www.actascientific.com/submission.php

Email us: editor@actascientific.com

Contact us: +919182824667 